\title{
Cultural Politeness: Developing a Multiple Perspectives Paradigm in Marketing Communication
}

\author{
Bahtiar Mohamad ${ }^{1, *}$, Sahid Teguh Widodo ${ }^{2}$, Ghadah Alarifi ${ }^{3}$, Muslim Akanmu \\ Diekola $^{4}$, Ahmed Rageh Ismail ${ }^{5}$ \\ ${ }^{1}$ Othman Yeop Abdullah Graduate of Business, Universiti Utara Malaysia, Kuala Lumpur, Malaysia \\ ${ }^{2}$ University Centre of Excellence Javanology for Javanese Traditions, Universitas Sebelas Maret, Solo, \\ Indonesia \\ ${ }^{3}$ College of Business Administration, Princess Nourah bint Abdulrahman University, Kingdom of Saudi Arabia \\ ${ }^{4}$ School of Technology Management and Logistic, Universiti Utara Malaysia, Kedah, Malaysia \\ ${ }^{5}$ School of International Business, Egypt Japan University of Science \& Technology (EJUST), Alexandria, Egypt \\ *Corresponding author.Email: mbahtiar@uum.edu.my
}

\begin{abstract}
This study aims to explore the roles of cultural politeness, a concept integrating intellect and moral values to shape the marketing communication behaviour and ethics from multiple cultural perspectives. This conceptual paper investigating how contemporary marketing communication practices are affected and manifested by existing knowledge of cultural politeness. The influence of cultural politeness can still be found in the contemporary business settings although its origins can be traced back to various civilization. For instance, marketing communication ethics in developing of promotion, advertising and branding content are related to the politeness behaviour. This study examined cultural concepts that are largely overlooked in the marketing literature in analysing cultural politeness in marketing communication from perspectives of western, African and Asian cultures. Although, the marketing communication is growing rapidly in business activities, only little scholarly attention has attempted to explore the cultural foundations and underpinnings that influence and shape marketing practices. Cultural politeness can serve as a potential catalyst for some desirable and particular practices of marketing communication including the great importance in giving social relations priority over work performance.
\end{abstract}

Keywords: Advertising, Communication Accommodation Theory, Cultural Politeness, Face Management Theory, Marketing Communication

\section{INTRODUCTION}

The effect of globalization has the assumption that congregating tastes and needs of consumers can be achieved by economic development which would standardize advertising and marketing [39]. Economy of scale in production can result to low price and high quality ratio which customer would prefer over brands or products they are used to. However, the other factor that affects consumer behaviour is the integrated values of the product/brand in their culture [38]. Therefore, the marketing communication is a best tool for business to incorporate the multiple cultural approaches into marketing communication strategies. For instances, marketing communication to international marketing has been recognized as a challenging issue from time immemorial [7], [13], [23]. Many previous studies confirmed that most of the problems in international marketing communication are as a result of different countries with different cultures [15], [21], [47].

A model for conceptualizing a national culture of the markets is needed by multinational companies to assess the relevance in culture of marketing communication. The marketers should be sensitized 
by understanding the underlying measures of cultural politeness in relation to the effectiveness of many promotional appeals and branding across countries with the same cultures is only opened up by unfolding the latent dimensions that influence cultural politeness and behaviour [3]. Such framework in assessing the cultural relevance of marketing communication is important in the present global society where there is pressure on firms to incorporate promotional appeal, advertising and branding with the local cultures. Therefore, this article has two objectives: (1) to investigate cultural politeness behaviour and its impact on the marketing communication; and (2) to discuss the multiple perspectives of cultural politeness in marketing communication. Hence, the following questions are asked in that respect:

What are the major factors in strategizing marketing communication that affect successful cultural politeness? How is cultural politeness practised in difference cultural context?

The other parts of this paper are organized as follow: related studies of culture, politeness and marketing communication were discussed in the first section. This is followed by a discussion of politeness theory and its applications in multiple culture contexts.

\section{LITERATURE REVIEW}

This section reviews the roles of local cultures in international marketing communication studies with special emphasis being given to local cultural frameworks. For instance, Li et al., [34] studied the marketing communication of global brands penetrating into the local markets and how frequent localized communication is used (e.g., integrating elements of local culture in the marketing communication) is used. The study found that, the significant effects of culturally polite communication on the consumers' evaluation of global brands does not occur with communication in another market but only occurs in the local markets. Also, global brand applying localization efforts can achieve strong localness perception that leads to significant and positive effects on brand evaluation. The need for culturally polite communication can even be overshadowed by a strong localness perception of the global brand.

According to Brown and Levinson [8] on politeness principles, global brand marketers can communicate with polite intention or respect towards the local culture to promote brand evaluation by the local consumers. This implies that more favourable evaluation of a global brand is realised with localization through marketing communication of cultural politeness only when it happens in the local but not in another market.

Holtgraves [27] stated that a politeness norm can be adopted by a foreign brand in order to overcome the individual devaluation of the localized communication as it would properly be received by a socially-distant recipient, that is the local consumers. As generally applicable in the concept of social norm communication, Brown and Gilman [9] defined politeness as a way the feeling of a hearer is considered by a speaker when utterance is constructed by a speaker in inter-personal communication. The need of people is catered for with politeness in order for a positive self-view to be maintained [9]. Thus, to avoid friction in interpersonal interaction, politeness serves as the function of cooperation [28].

Therefore, by showing politeness to the culture, global brands can show considerations for feelings of local consumers about their cultures in its marketing communication such as acknowledging and interpreting correctly the meaning of the elements of the local culture. By doing so, the expectation of the local consumers can be met as the foreign brands should respect and recognize the importance of the local culture to the self-identity of the consumers which leads to favourable responses to the brand. Yang et al., [53] reported that local consumers are more welcoming to foreign brands that incorporate high symbolic cultural elements that are important and meaningful into marketing communication.

Past studies show that as psychological distance increases, the demand for politeness increases [46]. That is when having conversation with higher social distance interlocutors, more polite languages are expected to be used by people e.g., interacting with strangers rather than friends [8]. When interacting with people who are more distant psychologically from the self, the expectation to follow the principles of politeness becomes stronger [46]. The study indicates that being polite is less critical in interpersonal relationship between individuals when there is smaller psychological distance (i.e., among in-group members). Thus, when there is strong localness perception for the global brand, culturally-polite communication would be less critical. That is, the need for culturally polite communication would be overshadowed by strong localness perception of the global brands in order to enhance the brand evaluation.

\section{CULTURE, POLITENESS AND MARKETING COMMUNICATION}

Culture is a shared given meaning described and assigned, not just the shared interpretation of behaviour but also the distinctions in behaviour 
comprising people and things [1], [45]. Different attitudes, values and norms are possessed by people from different backgrounds which indicate their cultural heritage [20]. In the same vein, culture is a widely shared practices and knowledge transferred across generations and it can form beliefs and selfconcept of the people [11]. The continuity and sharedness of culture protect an individual from epistemic error of unpredictability and uncertainty and provide for them a sense of epistemic security.

Since existing literature consist of multitude of definitions, defining culture concisely presents unexpected difficulties. Linton [35] has defined culture as "configurations of results of and learned behaviour whose component parts are transmitted and shared by the members of a specific society". Terpstra and David [47] offered the links between academic perspective and business context in application of culture: "Culture is a learned, shared, compelling, interrelated set of symbols whose meanings provide a set of orientations for members of a society. .."

Hall [22] posits that a set of symbols that an individual assimilate in a process of acculturation leads to "highly selective screen" in the mind of people allowing some stimuli through but rejecting others. These symbols are shared by members of the same culture which allows communication between the individuals in a given culture. With the same token, cross-cultural communication becomes difficult when there is no shared experiences and symbols.

Practitioners in international marketing need a conceptual schemata and appropriate framework for comparison. So far, approaches suggested are different from simple laundry lists of results from cultural distinctions to the highly theoretical framework of Triandis [49] as stated by Bochner [6].

The conception of cultural politeness stems from interpersonal politeness. Brown and Gilman [9] defined interpersonal politeness as a way the feelings of the hearer is taken into account by a speaker when an utterance is phrased by a speaker in inter-personal communication. Speaker basically selects a style that will not lead to uncomfortable feelings when he/she address a person. This is in line with the notion of politeness in many cultures which is part of their life and has been cultivating from since childhood.

There are many ways to be polite in the context of business. For example, businesses during advertisement or promotional material can appreciate the local cultural practices and traditions and highlight the positive elements of the culture. To be culturally polite, there are three possible ways. First is the acknowledgement of the local cultural values and practices. Second, emphasis on the importance of local culture in international events. Third, the combination of the two method early mentioned. Enhancing the relationship between the culture and self can lead to positive self-evaluation as culture is sued to define self [11]. The impact of culture on marketing is ubiquitous and multi-faceted. It affects people's attitudes towards product classes, tastes and preference for colours. According to Triandis [49], how information is received, stored, retrieved and deployed is greatly affected by culture in decision-making. Thus, the marketing communication process of an organization planning to enhance sales of a product and service is significantly affected by the cultural milieu of society.

During the course of marketing communication, information to persuade the buyer towards the offering of the sellers favourably is selectively and carefully selected. Both the style and the content of the seller's communication are culturally-based just like the processing of the buyer of the resultant decision and information. In the context of marketing communication, Brown and Levinson [8] mentioned that people care about politeness during formal and informal interaction as politeness serves as a function of cooperation and to maintain positive self-view. Such gesture of culture politeness in marketing communication indicate the intention of the marketers to understand the importance of local culture to consumer self-identity and what the local culture means to local consumers.

For example, marketing communication is struggling for a balance to link the pieces of the marketing mix to each region or country. Customizing to every market is effective but costly while standardizing one method across the world is mostly ineffective but efficient. The solution is offered by an approach in accordance with cultural differences i.e. effective impact and efficiency. Therefore, when a foreign brand gains entry into a local market in order to facilitate cooperation among local consumers with the foreign brands (i.e., marketing messages persuading purchase of a product) and to manage the relationships with the local communities in the context of intercultural marketing communication, consideration for local consumer feelings can be shown by the foreign brands about their culture by being polite to the culture.

It is important from the standpoint of the seller that the culture of the buyer be understood in order to make effective process of communication. This is especially crucial in mass-selling approaches like advertising when there is no chance for the seller to change their appeal and feedback is given by the buyers. The problem of communicating to people of different culture is one of the greatest issues in marketing communication [42]. This is because, 
cultural factors are difficult to comprehend as they are operating typically below the level of conscious awareness. How various phenomena are perceived are determined largely by the culture.

According to Barnlund [5], culture is communication as believed by scholars of crosscultural communication. For an effective communication, there must be psychological overlap between the sender and receiver in the perpetual field of the sender - his/her map of the world must be in agreement with the receiver's perpetual field. A message falling outside the perpetual field of the receiver cannot transmit the intended meaning of the sender and will likely transmit unintended meaning by the sender. Serious marketing mistakes are always made in this area even companies with vast experience in multinational marketing are not exempted [41], [42], [43].

A framework for cultural classification can enhance the success of a marketers' endeavours to incorporate advertising, promotional appeals and branding to diverse cultures. A marketer can develop and implement marketing communication strategies that lead to optimum outcomes once there is a framework in assessing the cultural domain of the given country. Also on the basis of cultural similarities between two countries, a classification can allow marketer to extend marketing communication strategy from one country into another. Thus, the proposed formwork by Hofstede [25], [26] has the greatest implementation in this area.

\section{UNDERPINNING THEORY}

This paper is based on a combination of two main theories: Communication Accommodation Theory and Face Management Theory. According to Giles and Ogay [18], communication accommodation theory posits that when approval is needed from individuals, they tend to use convergence strategies to adapt their communicative behaviour to be more similar to the behaviour of their interlocutors. For instance, a local accent is adopted by a foreigner to accommodate the communication pattern of the local people. In this stance, including elements of local culture in marketing communication represents a convergence strategy by global brand as these local elements can activate the knowledge of local culture of the recipient and enhance comprehension of the communication [29]. In marketing communication of a global brand, the expectation of local consumers aligns with cultural politeness on appropriate level of using local cultural elements [34]. Also, the theory as mentioned by Giles and Ogay [18] suggests that the expectation of the interaction about levels of accommodation is determined by the stereotypes about the out-group members. The recipients' expectations about the appropriate behaviour to be used in the situation and the adequate level of convergence determine whether the recipients will have negative or positive reactions towards the convergence strategy [17]

While the theory of communication accommodation is concerned with understanding how convergence strategy is used in adapting their communicative behaviour, how motivated people are to manage and protect their public image-self when a threat is posed to the public self-image is highlighted by the face management theory [55]. Any action that is viewed as threatening to the public image of self is considered face-threatening. However, face threat appears to be almost unavoidable. For example, considering various actions of interpersonal interaction, the face of speaker appears threatened when the hearers say no (i.e. the need of the speaker is not fulfilled) whenever a hearer is asked by the speaker to do something. Also, if he/she says yes, the face of the hearer is threatened (i.e. the hearer is obliged to act on the request of others). Therefore, the necessity to perform face-threatening acts and for face maintenance on the parts of both parties position social interactions into dilemma. According to Holtgraves [28], solving a dilemma with being polite is effective in order to avoid conflicts in interpersonal interaction and to serve the function of cooperation. Positive image can be maintained by both the speaker and the hearer through politeness and by showing consideration towards feelings of each other. Similarly, no pressure or coercion is felt by the hearer to cooperate with the speaker.

Furthermore, people in a society are informed by culture on what behaviour, practices, beliefs and values are considered true, appropriate and important [12]. Therefore, people connect themselves to the culture and may acclimatize themselves to particular cultural elements as part of their self [11]; that is their self is defined using a particular culture. Cultural self is used as a construct by Hong et al., [30] to capture the connection between self and culture which refers to the self which is defined with reference to the traditions and knowledge (e.g., beliefs, practices, values) shared in a particular culture. The need to protect and maintain cultural self becomes stronger when there is cultural mixing since fears of threats to continuity and integrity of the native culture is evoked by cultural mixing [11]. This theory is fit to direct a marketing communication activity that involves negotiation between the seller and buyer. 


\section{POLITENESS IN MULTIPLE CULTURES}

Although there cross cultural difference in what is believed to be polite, the concern for politeness across different culture is universal. The westerners care about autonomy-related face while African and Asian are care about community-related face more [56]. There are needs for positive regard in all the three cultures but westerners care about individualistic attribute, while Africans and Asians care about collective attributes [44].

First, the researches have been done by many scholars on the phenomenon of "politeness" and their theories and perspectives are proposed on the largest sub Asian cultures in China. For example, Gu [19] reported that, there are four basic concepts in traditional Chinese "politeness"; they are: refinement, respectfulness, modesty and attitudinal warmth. Social status and others' faces are affirmed by respectfulness; another way of saying to debase oneself is modesty; the expression of concern and friendliness from self to others is referred to as attitudinal warmth; and forbidding bawdry and choosing elegant expression is termed refinement. To respect the positive face of other is the concepts of face in the perception of respectfulness [24].

In another vein, the perception of modesty is explained into debasing only oneself in Chinese culture although lies in different culture. The concept of attitudinal warmth is a threat to the negative face of others and violates the freedom of others [8]. Meanwhile, this is not considered as face-threatening action in contemporary Chinese language. Politeness normativeness is represented by the conception of refinement. Although politeness is universal, the research of Brown and Levinson [8] mentions no "refinement". On the incorporation of the four basic concepts of traditional Chinese "politeness" and politeness principle of Leech [19], [33] proposed sequence of principles: attitudinal warmth, respectfulness, modesty, generosity maxim, refinement and tact maxim that are considered for the contemporary Chinese language.

As past researches suggest that customer perception of satisfaction and risk can be influenced by culture, politeness is proposed then as a culturally specific concept [31]. The empirical study by Marti [37] regarding culture-specific politeness has revealed that, the degree of politeness and conception of politeness are not similar in different culture. Therefore, the difference in the perception of politeness may lead to conflict or misunderstanding in intercultural interaction. Thus, Liu et al., [36] investigated the cultural meaning of employee's attributes by incorporating the Chinese traditional philosophy, li (i.e. Politeness) into a service, marketing by evaluating its comparative impacts with other features. For example, sales promotion and advertising in marketing communication play significant roles in Chinese's business and economic development [54]. Therefore, culturally-specific politeness in the context of marketing communication probably triggers ethical issues in cross-cultural and international marketing communication such as reciprocity in exchanging respect with each other [10]. A marketer without this kind of knowledge can be at risk of violating these principles of marketing politeness (e.g. Underplay or overdue of the politeness behaviour) which can lead to damaging customer relations or ethical issues of harassment.

In the specific context of Asian culture such as Malays, the concept of politeness always refers to respect, patience and gratitude [2]. The basic politeness in Malay culture can be seen such as cultural value deemed appropriate to the society. The integrated entity of politeness strategies and basic politeness are considered constrained politeness. It is constrained by the consideration of who speaks what, at where, why, to whom and how the similarities are seen in the construct of politeness. Inevitably, this results to inter-connectedness of politeness strategy with cultural values where whatever facets of human relationship that are valued by a culture will be given prominence and manifested in the politeness strategy of the speaker.

In Asian culture that is central to its politeness and its values as manifested in a specific context including in the business setting. For instance, some particular cultural concepts of Malay culture like "budi" (right thinking, mind, reason) and "adab" (manners, proper behaviour, tradition and custom) practices in business negotiation and marketing communication. As a marketer, the 'adab' and 'budi' need to embed in their strategy for winning the Malays heart. The Islamic values always a pillar for the cultural politeness among Malays. For instance, the Malays majority regions in east coast peninsular Malaysia also known as 'Malay belts', the marketers take care the sensitivity of the community. The billboard are used Arabic characters (Jawi) and the model covers their 'aurat' for both male and female. The cultural sensitivity is one of the important elements for the marketer to communicate to their customer.

Secondly, in the western context, the concepts of politeness are derived from face theory and politeness principle by Goffman [55], Brown and Levinson [8] and Leech [33] respectively. According to Brown and Levinson [8], each rational, member of a society has his own face which is divided into two groups in 
accordance with the need of an individual: positive and negative face. The former shows that the image of a positive individual to be praised and the need to be approved and the former represents how people have freedom of action without interference. The face has duality aspect which is contradictory. Levinson distinguishes interaction aspect as positive politeness while it is known as positive face. The discourse strategy which is usually made use of by "positive face" is to show interest and give attention to the speech of others with respect in order to make it clear that the two communicators have similar feature. The negative face is acknowledged as the independent aspect of politeness which Levinson considered as "negative politeness".

There are three three-way interaction measures of politeness for "positive face" in the western context (i.e. Friendliness, helpfulness and respectfulness) that jointly and positively influence customer satisfaction, which is in consistency with past studies [32], [52]. This is also in line with the study of Rego et al., [40] that customer satisfaction has been a central of discuss in the marketing literature being a key concept for international marketers. Van Quaquebeke and Eckloff [51] argued that if customers are not respectfully treated, they may feel dissatisfied and insulted, and then take their businesses somewhere else. In lieu of that, respect is regarded as a process aimed to recognize, appreciate and communicate the worth and importance of the customer to satisfy the need of the customer for social regard or self-esteem in the customer-brand relationship.

Thirdly, Deberry-Spence et al., [14] examined the cultures in Africa in relation to business markets and its implication for marketing practices. The study revealed that the reciprocity principles in seller-buyer interaction is promoted in African culture, positing that foreign companies need take cognizant look to the softer issues on the relationships and to high ranking employee team in order to achieve win-win and longterm results. Although African culture is overarching, the study concludes that international marketers dealing in African business markets must understand that least resistance will be received by policies that are in consistency with the value system. Also, a high cultural sensitivity can promote trust in buyer-seller interaction; and non-verbal context and communication should be given attention.

Similarly, in the context of Africa considering countries from distinctive regions (Nigeria, Kenya, South Africa, Ghana and Egypt), Ukpabi et al., [50] reported a cross-national study on consumers' perception and reviews on hotel service. In a highcontext culture like Africa, interpersonal relationship are important to social cohesion regarding staff relational services. Thus, politeness, courtesy and friendliness are not only an integral of the corporate culture but also synonymous with the African social system.

Fasasi et al., [16] confirmed that irrespective of the advertising strategies adopted by marketers of goods and services, the choice of language can still make or mar the entire process of advertising in Nigeria. Analysis reveals that herbal drug advertisements are characterized by a few polite and face-enhancing speech acts which include seeking attention, greetings and dramatic conversation and, a profusion of impolite and face-threatening acts which include direct command, insults, unwarranted question and claim of multiple benefits. In general, perceived cultural politeness of consumer and marketer intention of being culturally polite may be involved in marketing communication. Therefore, consumers and marketers may have different interpretation of what cultural politeness is.

In another word, cultural politeness is applicable most in an intercultural context in evaluating a brand when two important conditions are met: first, the brand is considered to be an out-group culture brand (i.e. The foreign brand); second, the brand is perceived to engaging the local culture (i.e. Involving intercultural context). Although, in intercultural context, cultural politeness is much common; this is not an indication of no relevance with the local brand. Violation of cultural tradition and values from the local brands also lead to perception of cultural impoliteness. However, when the brand is from an out-group culture (i.e., the foreign brand), the effect of cultural politeness on consumer responses is much stronger.

A foreign brand can be culturally polite or personally polite in acting in a polite manner in marketing communication, but the consumers may have diverse subjective perceptions. Stronger cultural politeness in a communication is said to be perceived by local consumers when a brand communicates in a culturally polite manner than when the brand communicates in a personally polite manner. However, communication is perceived by consumers to be personally perceived when a brand communicates in a culturally or personally polite manner as culture is part of the self. When the brand is locally polite to the culture, the local consumers will also feel personal politeness.

\section{CONCLUSION}

Increasingly, it is becoming necessary for global brands to integrate elements of culture into their marketing communication in order to promote 
receptiveness of their products in local markets. The perceived cultural politeness of the communicated message is one of the defining factors of the failure or success of marketing communication involving a cultural element. It is noted that importance of cultural intention is given more priority than the cultural abilities regarding the effects of cultural politeness. Thomas et al., [48] reported that building cultural abilities and increasing awareness of cultural differences can lead to effective management of the response of local people such as improvement of cultural skills and language [4]. The local brand should negotiate more effectively with the local market by integrating cultural localness and politeness perception. Therefore, local consumers can perceive higher brand warmth through culturally polite communication if the brands are not in any case perceived as local which on the long or short run increases the brand acceptance by the local consumers. Finally, politeness has often been examined in isolation (and hence its pervasiveness) while this conceptual study has been designed under the assumption that it is not an isolated factor in communication and perception but simultaneously operates with other dimensions that are part of the communicative experience itself.

\section{AUTHORS' CONTRIBUTIONS}

All authors contribute to the content of the paper from the beginning to the end of writing the paper.

\section{ACKNOWLEDGMENTS}

This research was funded by the Deanship of Scientific Research at Princess Nourah Bint Abdulrahman University through the Fast-track Research Funding Program and thanks to University Centre of Excellence Javanologi for Javanese Traditions Universitas Sebelas Maret for funding the publication

\section{REFERENCES}

[1] Bakar, H.A. Bakar, Mohamad, B., Halim, H., Subramaniam, C., \& Choo, L.S (2018). Shared cultural characteristics similarities in Malaysia's multi-ethnic society. Journal of Intercultural Communication Research, 47(3): 243-267.

[2] Asmah, H.O. (1984). Kaedah Pengajaran Bahasa. Kuala Lumpur: Dewan Bahasa dan Pustaka, Kementerian Pelajaran, Malaysia.

[3] Bakar, H.A., Halim, H., Mustaffa, C.S., \& Mohamad, B. (2016). Relationships differentiation: Cross-ethnic comparisons in the
Malaysian workplace. Journal of Intercultural communication research, 45(2), 71-90.

[4] Barner-Rasmussen, W., Ehrnrooth, M., Koveshnikov, A., \& Makela, K. (2014). Cultural and language skills as resources for boundary spanning within the MNC. Journal of International Business Studies, 45(7), 886-905. https://doi.org/10.1057/jibs.2014.7

[5] Barnlund, D.C. (1989), Communicative Styles of Japanese and Americans: Images and Realities, Wadsworth Publishing Company, Belmont, CA

[6] Bochner, S. (1982), Cultures in Contact, Pergamon Press, Oxford

[7] Boddewyn, J.J. (1981), The Global Spread of Advertising Regulations', MSU Business Topics, Spring, 6-13.

[8] Brown, P., \& Levinson, S.C. (1987). Politeness: Some universals in language usage. Cambridge University Press

[9] Brown, R., \& Gilman, A. (1989). Politeness theory and Shakespeare's four major tragedies. Language in Society, 18(2), 159-212. https://doi.org/10.1017/S0047404500013464

[10] Chan, G. K. Y. (2008). The relevance and value of Confucianism in contemporary business ethics. Journal of Business Ethics, 77, 347-360.

[11] Chiu, C.Y., Gelfand, M.J., Yamagishi, T., Shteynberg, G., \& Wan, C. (2010). Intersubjective culture: The role of intersubjective perceptions in cross-cultural research. Perspectives on Psychological Science, 5(4), 482-493.

[12] Chiu, C.Y., Morris, M.W., Hong, Y.Y., \& Menon, T. (2000). Motivated cultural cognition: The impact of implicit cultural theories on dispositional attribution varies as a function of need for closure. Journal of Personality and Social Psychology, 78(2), 247.

[13] Colvin, M., Heeler, R. and Thorpe, J. (1980), Developing International Advertising Strategy, Journal of Marketing, 44, Fall, 73-9.

[14] Darley, W.K. \& Blankson, C. (2008), African culture and business markets: implications for marketing practices, Journal of Business \& Industrial Marketing, 23(6), 374-383. https://doi.org/10.1108/08858620810894427

[15] Elinder, E. (1965), How International Can European Advertising Be? Journal of Marketing, 29, April, 7-11. 
[16] Fasasi, K.A., Njoku, N.C., \& Onuabuobi, O.S. (2018). Politeness in Advertising among Herbal Drug Sellers in Owerri Metropolis. Journal of Language and Linguistics, 4, 1-16

[17] Gallois, C., \& Callan, V.J. (1991). Interethnic accommodation: The role of norms. In H. Giles, J. Coupland, \& N. Coupland (Eds.), Contexts of accommodation: Developments in applied sociolinguistics (pp. 245-269). Cambridge University Press

[18] Giles, H., \& Ogay, T. (2007). Communication accommodation theory. In B. B. Whaley \& W. Samter (Eds.), Explaining communication: Contemporary theories and exemplars (pp. 293310). Lawrence Erlbaum

[19] Gu, Y.G. (1992). Politeness, pragmatics and culture. Foreign language teaching and research, $4(2), 10-17$

[20] Halim, H., Bakar, H. A., \& Mohamad, B. (2019). Expatriation in Malaysia: Predictors of CrossCultural Adjustment among Hotel Expatriates. International Journal Supply Chain Management, 8(1), 664-675

[21] Hall, E.T. (1960), The Silent Language in Overseas Business, Harvard Business Review, 38, May-June, 93-6.

[22] Hall, E.T. (1976), Cultures Collide, Psychology Today, July, 66-7.

[23] Harris, G. (1984), The Globalization of Advertising, International Journal of Advertising, 3 223-34.

[24] He, Z. X., Yu, D. M., Hong, G., \& Wang, J. (2000). A new introduction to pragmatics. In Shanghai: Shanghai Foreign Language Education Press.

[25] Hofstede, G. (1980), Motivation, Leadership and Organization: Do American Theories Apply Abroad? Organizational Dynamics, 9, Summer, 42-63.

[26] Hofstede, G. (1984), Culture's Consequences: International Differences in Work-Related Values, Sage Publications, Beverly Hills, CA.

[27] Holtgraves, T. (2002). Language and social action: Social psychology and language use. Lawrence Erlbaum.

[28] Holtgraves, T. (2010). Social psychology and language: Words, utterances, and conversations. In S. T. Fiske, D. T. Gilbert, \& G. Lindzev (Eds.),
Handbook of social psychology (5th ed., Vol. 1, 1386-1422).

[29] Hong, Y.Y., Morris, M.W., Chiu, C.Y., \& BenetMartinez, V. (2000). Multicultural minds: A dynamic constructivist approach to culture and cognition. American psychologist, 55(7), 709.

[30] Hong, Y. Y., Wan, C., No, S., \& Chiu, C. Y. (2007). Multicultural identities. Guilford Press.

[31] Keh, H.T., \& Sun, J. (2008). The complexities of perceived risk in cross-cultural services marketing. Journal of International Marketing, 16(1), 120-146.

[32] Keh, H.T., Ren, R., Hill, S.R., \& Li, X. (2013). The beautiful, the cheerful, and the helpful: The effects of service employee attributes on customer satisfaction. Psychology \& Marketing, $30(3), 211-226$.

[33] Leech, G. (2007). Politeness: is there an EastWest divide? Journal of Politeness research, 3(2), 167-206.

[34] Li, D., Kreuzbauer, R., Chiu, C.Y., \& Keh, H.T. (2020). Culturally polite communication: enhancing the effectiveness of the localization strategy. Journal of Cross-Cultural Psychology, 51(1), 49-69.

[35] Linton, R. (1945), The Cultural Background of Personality, Appleton-Century-Crofts, New York.

[36] Liu, M. T., Yan, L., Phau, I., Perez, A., \& Teah, M. (2016). Integrating Chinese cultural philosophies on the effects of employee friendliness, helpfulness and respectfulness on customer satisfaction. European Journal of Marketing, 50(3/4), 464.

[37] Marti, L. (2006). Indirectness and politeness in Turkish-German bilingual and Turkish monolingual requests. Journal of Pragmatics, 38(11), 1836-1869.

[38] Raji, R.A., Mohd Rashid, S., Mohd Ishak, S., \& Mohamad, B. (2020). Do firm-created contents on social media enhance brand equity and consumer response among consumers of automotive brands? Journal of Promotion Management, 26(1), 19-49.

[39] Raza, S.H., Bakar, H.A., \& Mohamad, B. (2018). Advertising appeals and Malaysian culture norms: Scale content validation. Journal of Asian Pacific Communication, 28(1), 61-82. 
[40] Rego, L. L., Morgan, N. A., \& Fornell, C. (2013). Reexamining the market share-customer satisfaction relationship. Journal of Marketing, 77(5), 1-20.

[41] Ricks, D.A. (1983), Big Business Blunders: Mistakes in Multinational Marketing, Dow Jones-Irwin, Homewood, IL.

[42] Ricks, D.A. (1988), International Business Blunders: An Update" Business and Economic Review, 34, January-February-March, 11-14.

[43] Ricks, D.A., Fu, M. and Arpan, J. (1974), International Business Blunders, Grid, Columbus, $\mathrm{OH}$.

[44] Sedikides, C., Gaertner, L., \& Toguchi, Y. (2003). Pancultural self-enhancement. Journal of personality and social psychology, 84(1), 60.

[45] Smith, P.B., Peterson, M.F., \& Schwartz, S.H. (2002). Cultural values, sources of guidance, and their relevance to managerial behavior: A 47nation study. Journal of cross-cultural Psychology, 33(2), 188-208.

[46] Stephan, E., Liberman, N., \& Trope, Y. (2010). Politeness and psychological distance: A construal level perspective. Journal of Personality and Social Psychology, 98(2), 268280. https://doi.org/10.1037/a0016960

[47] Terpstra, V. and David, K. (1985), The Cultural Environment of International Business, $2^{\text {nd }}$ ed., Southwestern Publishing Co., Cincinnati, $\mathrm{OH}$.

[48] Thomas, D. C., Liao, Y., Aycan, Z., Cerdin, J. L., Pekerti, A. A., Ravlin, E. C., ... \& Moeller, M. (2015). Cultural intelligence: A theory-based, short form measure. Journal of International Business Studies, 46(9), 1099-1118.

[49] Triandis, H.C. (1972), The Analysis of Subjective Culture, Wiley, New York

[50] Ukpabi, D., Olaleye, S., Mogaji, E., \& Karjaluoto, H. (2018). Insights into online reviews of hotel service attributes: A cross-national study of selected countries in Africa. In Information and communication technologies in tourism 2018 (pp. 243-256). Springer, Cham.

[51] Van Quaquebeke, N., \& Eckloff, T. (2010). Defining respectful leadership: What it is, how it can be measured, and another glimpse at what it is related to. Journal of Business Ethics, 91(3), 343-358.

[52] Wan, W.W., Luk, C.L., Fam, K.S., Wu, P., \& Chow, C.W. (2012). Interpersonal relationship, service quality, seller expertise: How important are they to adolescent consumers? Psychology \& Marketing, 29(5), 365-377.

[53] Yang, D. Y.-J., Chen, X., Xu, J., Preston, J.L., \& Chiu, C.-y. (2016). Cultural symbolism and spatial separation: Some ways to deactivate exclusionary responses to culture mixing. Journal of Cross-Cultural Psychology, 47(10), 1286-1293

[54] Zhu, Y. (2009). Confucian ethics exhibited in the discourse of Chinese business and marketing communication. Journal of Business Ethics, $88(3), 517-528$

[55] Goffman, E. (1967). On face-work. Interaction ritual, 5-45.

[56] Friedman, R., Olekalns, M., \& Oh, S. (2011). Cross-Cultural difference in reactions to facework during service failures. Negotiation and Conflict Management Research, 4(4), 352-380. 